\title{
Estimating primary production rates from photosynthetic electron transport in estuarine microphytobenthos
}

\author{
Christiane Barranguet ${ }^{1,2}$, Jacco Kromkamp ${ }^{1, *}$ \\ ${ }^{1}$ Netherlands Institute of Ecology, Centre for Coastal and Estuarine Ecology (NIOO-CEMO), PO Box 140, \\ 4400 AC Yerseke, The Netherlands \\ ${ }^{2}$ University of Amsterdam, Department of Aquatic Ecology and Ecotoxicology, Kruislaan 320, 1098 SM Amsterdam, \\ The Netherlands
}

\begin{abstract}
Microphytobenthos primary production was measured using $\mathrm{C}$ fixation and compared with production estimates based on measurements on intact cores using variable chlorophyll fluorescence with a PAM (pulse-amplitude-modulated) fluorometer at a number of different sites on intertidal flats in the Westerschelde and Oosterschelde estuaries (The Netherlands). We observed a linear relationship between the minimal fluorescence, $F_{0}$, and the chlorophyll a content of the sediments, but the relationship was quite noisy, which was partly due to a vertical scale mismatch between the depth of sampling $(1 \mathrm{~mm})$ and the measuring depth the of PAM fluorometer (100 to $200 \mu \mathrm{m})$. On most sites, C fixation was a linear function of photosystem II electron transport (ETR, obtained from PAM measurements), although for Stn B, a relatively silty site on the Molenplaat, an intertidal flat in the Westerschelde, the agreement between $\mathrm{C}$ fixation and ETR was often non-linear at irradiances saturating $\mathrm{C}$ fixation. This was sometimes observed for some of the other stations as well. The differences at high irradiance might be related to vertical migration of epipelic diatoms, optical properties of the sediment or alternative electron acceptors. A conversion factor was calculated, allowing estimation of $\mathrm{C}$ fixation from ETR measurements. This conversion factor was not different for the different stations and no clear seasonal influence was observed, although the conversion factor could vary within hours. The seasonally averaged conversion factor for all stations and each site was used to calculate areal rates of production and compared with primary production estimates obtained from the C fixation measurements. It appeared that the PAM-based estimates gave a good prediction of the (potential) C fixation, with the exception of a number of dates for Molenplaat Stn B. This demonstrates that the variable fluorescence technique can become, after further calibration with ${ }^{14} \mathrm{C}$ for other shallow sediments, a very useful tool in production studies, and can be instrumental in obtaining a good spatial coverage of primary production, which remains very difficult due to the patchiness in microphytobenthos biomass and production.
\end{abstract}

KEY WORDS: Chlorophyll fluorescence · Photosynthetic electron transport $\cdot$ C fixation · Microphytobenthos $\cdot$ Primary production $\cdot$ Tidal flats

\section{INTRODUCTION}

From estuarine ecosystem models (de Jong \& de Jonge 1995) it appears that microphytobenthos is an important compartment, and is one of the principal

${ }^{*}$ Corresponding author.

E-mail: kromkamp@cemo.nioo. knaw.nl agents responsible for carbon input into the entire system (Sullivan \& Montcreiff 1988). Its importance is well documented and widely recognized (MacIntyre et al. 1996); but the appropriate methodology for measuring primary production of benthic microalgae is still under discussion (Revsbech et al. 1981, Underwood \& Kromkamp 1999). The fast changes in production rates, the marked rhythms in photosynthesis and verti- 
cal migration and the steep vertical gradients in the sediments all make it difficult to get a good picture of the actual production with appropriate scaling. In combination with the marked spatial heterogeneity in biomass, it means that estimates of primary production by microphytobenthos cannot be very precise. The discussion about which method to use for a better estimation of microphytobenthos production rates is quite extensive in the literature (Underwood \& Kromkamp 1999, and references therein), but there is a general consensus that all techniques have their own advantages and limitations and they should be regarded more as complementary than as antagonistic.

Variable fluorescence emerges as a new, promising and non-intrusive tool to estimate photosynthesis in phytoplankton (Kolber \& Falkowski 1993). The principle of variable fluorescence is also used by the PAM (pulse-amplitude-modulated) fluorometers (Schreiber et al. 1986, 1995) and this technique has been used to measure algal photosynthesis, although mainly on cultures (Kroon et al. 1993, Hofstraat et al. 1994, Kroon 1994, Geel et al. 1997, Flameling \& Kromkamp 1998). Although the pump and probe technique (see Falkowski et al. 1986, Kolber \& Falkowski 1993; later modified to the fast repetition rate fluorometer; Kolber et al. 1998) and the PAM technique use a similar physiological principle, some important differences exist, the most important being the fact that the pump and probe technique uses a saturating single turnover pump flash to measure the maximum fluorescence, $F_{\mathrm{m}}$, whereas the PAM technique uses a saturating multiple turnover flash (varying between 50 and $2000 \mathrm{~ms}$ ) to reach $F_{\mathrm{m}}$. As a result, the quantum efficiency of photosystem II (PSII) is lower when measured with a pump and probe compared to a PAM fluorometer (Schreiber et al. 1995), but in ecological applications the differences between these 2 techniques are probably not so large.

For microphytobenthos, however, only 3 papers up to now report the use of the PAM technique. Two of them measured quantum efficiency of PSII, and calculated photosynthetic electron transport rates (ETR) from these (Hartig et al. 1998, Kromkamp et al. 1998). Serôdio et al. (1997) used the minimal fluorescence to follow vertical migration of microalgae. Kromkamp et al. (1998) investigated whether the PAM technique could be used to estimate microphytobenthic production in situ, but it does not contain comparison with other techniques. Hartig et al. (1998) report the comparison between production measurements of the motile fraction of microphytobenthos by ${ }^{14} \mathrm{C}$ uptake and PAM in vitro in June. Although ${ }^{14} \mathrm{C}$-uptake experiments with sediment slurries can be useful to measure photosynthetic parameters, it is difficult to calculate in situ production from these estimates as the chemical microgradients existing in the sediments are destroyed. ${ }^{14} \mathrm{C}$-slurry techniques therefore give a potential estimate of the maximum primary production rates, and only under conditions when light is the main limiting factor will such estimates give an accurate prediction of in situ rates, in agreement with oxygen microelectrodes (Barranguet et al. 1998). On the other hand, there is no evidence that nutrients may become limiting for microphytobenthos in cohesive sediments so ${ }^{14} \mathrm{C}$ remains a useful standard technique (Admiraal et al. 1982, Barranguet et al. 1998, Underwood et al. 1998, Underwood \& Kromkamp 1999). There is obviously a need for more validation of the PAM technique as a measure of actual production rates of microphytobenthos, compared to other available and more standard techniques.

We report here the result of monthly measurements of photosynthesis irradiance $(P-E)$ curves on 2 tidal flats with the PAM fluorometer on intact cores (thus both motile and non-motile fraction included) and compared these with ${ }^{14} \mathrm{C}$ fixation measurement of diluted slurries.

Previous studies showed that the non-motile fraction can constitute an important part of microphytobentic biomass on sandy sediments in the Westerschelde (Barranguet et al. 1997, Sabbe 1997) and that migration of algae can account for variations of production during ebb tide (Barranguet et al. 1998, Kromkamp et al. 1998).

Our aim was to use the minimal (i.e. dark-adapted) fluorescence $\left(F_{0}\right)$ as an indicator of microphytobenthic biomass (as measured by chlorophyll a [chl a] concentrations) and to compare rates of photosynthesis and areal primary production obtained with both PAM and ${ }^{14} \mathrm{C}$ fixation.

\section{MATERIAL AND METHODS}

Sampling sites, physical and chemical measurements. The Molenplaat is a tidal flat located in the Westerschelde (SW Netherlands). The sampled stations (Molenplaat Stns A and B, Ecoflat Stns 1, 2, 3 and 4) have different sedimentary features, which are described in Table 1. An additional muddy-sand station located in a tidal flat in the Oosterschelde (Vondelingenplaat Stn V) was sampled for comparison with other nutrient concentrations in the overlying water, as the Oosterschelde waters are much poorer in nutrients than those of the Westerschelde. The location of the sampling sites can be found in Fig. 1.

PAR (photosynthetic available radiation) was measured during low tide with a cosine sensor LI 192SB connected to a Li-Cor Data Logger LI-1000. Data were integrated every $10 \mathrm{~min}$. Temperature was recorded in the field with a RD-Temp Omega temperature data logger at 5 min intervals. 
Table 1. Sediment characteristics and attenuation coefficients of the different sampling stations. See Fig. 1 for station locations

\begin{tabular}{|lcccc|}
\hline Stn & $\begin{array}{c}\text { Mean grain } \\
\text { size }(\mu \mathrm{m})\end{array}$ & $\begin{array}{c}\text { Silt content } \\
(\%)\end{array}$ & $\begin{array}{c}\text { Organic C } \\
(\%)\end{array}$ & $\begin{array}{c}\text { Average } K_{\mathrm{d}} \\
\left(\mathrm{mm}^{-1}\right)\end{array}$ \\
\hline $\mathrm{A}$ & 268 & 10 & 0.07 & 1.98 \\
$\mathrm{~B}$ & 241 & 16 & 0.16 & 4.24 \\
1 & 147 & 24 & 0.29 & 2.4 \\
2 & 73 & 43 & 0.64 & 4.82 \\
3 & 185 & 14 & 0.20 & 4.3 \\
4 & 196 & 5 & 0.06 & 2.39 \\
\hline
\end{tabular}

Samples were always taken during ebb tide (between 3 and $5 \mathrm{~h}$ of emersion), at dates when the minimum water level was around noon. One $4.7 \mathrm{~cm}$ diameter core was taken for the PAM measurements at the beginning of the emersion period. Cores for chlorophyll and ${ }^{14} \mathrm{C}$ production $(2.5 \mathrm{~cm}$ diameter, 6 cores at close proximity) were taken 3 times during ebb tide. The sediment was extruded from the core in $1 \mathrm{~mm}$ slices with a piston manipulated with a screw, one whole turn equivalent to $1 \mathrm{~mm}$. The samples for chl a were frozen on board until analyses. Pigments were extracted from freeze-dried samples with methanol (95\%) buffered with ammonium acetate (5\%) and were sonicated for 10 min. Chl a was analyzed by HPLC as in Barranguet et al. (1997). The results are expressed in $\mathrm{mg} \mathrm{chl} \mathrm{a} \mathrm{m} \mathrm{m}^{-2}$ for the first $\mathrm{mm}$ of sediment only. $F_{0}$ was obtained from the dark values during the measurement of the $P-E$ curves with the PAM fluorometer.

Primary production measurements. Fluorescence measurements: Variable fluorescence was measured with a PAM 101-103 fluorometer (Walz Effeltrich, FRG), which controlled the FL-103/E light source (type Schott KL1500/E) used for administering the saturating irradiance pulses. Ten photon flux density (PFD) exposures (2 min each), ranging from 0 to $1500 \mu \mathrm{mol} \mathrm{m}{ }^{-2} \mathrm{~s}^{-1}$, were made, in order to construct photosynthesis (i.e. ETR) irradiance curves, which were fitted according to Platt \& Jassby (1976), using a least square method. The $95 \%$ confidence interval was generally less than $4 \%$ of the mean. The photon irradiance was adjusted by changing the voltage of the FL-101/E (a Schott KL1500 lamp) fiber illuminator. The actinic light from the FL101/E and the saturating flashes from the FL-103/E were fed into the branches of the armed fiberoptics (101-F5, Walz). The tip of the fiberoptic was mechanically positioned perpendicular to the core surface, and the distance to the core surface was approximately $2 \mathrm{~mm}$. Details can be found in Kromkamp et al. (1998).

The maximum energy conversion efficiency or quantum efficiency of PSII charge separation $\left(F_{\mathrm{v}} / F_{\mathrm{m}}\right)$ is calculated as:

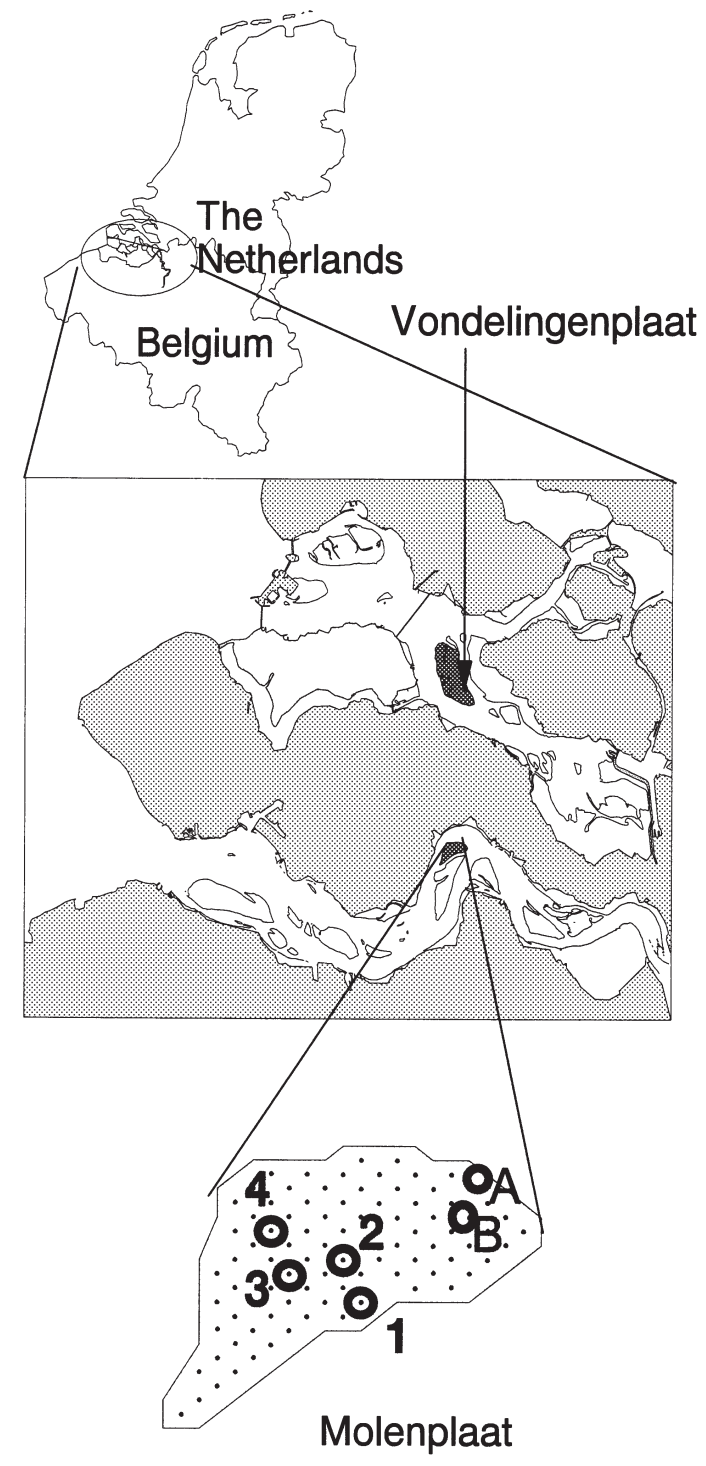

Fig. 1. Location of the sampling sites. On the Molenplaat in the Westerschelde estuary, the Ecoflat stations are numbered 1 to 4 , whereas the standard stations are designated A and B. The Vondelingenplaat with Stn V is located in the Oosterschelde estuary. Arrow: location of the sampling site on this intertidal area

$$
F_{\mathrm{v}} / F_{\mathrm{m}}=\left(F_{\mathrm{m}}-F_{0}\right) / F_{\mathrm{m}}
$$

where $F_{0}$ is the minimum fluorescence and $F_{\mathrm{m}}$ is the maximum fluorescence yield of a minimally $15 \mathrm{~min}$ dark-adapted sample. $F_{\mathrm{v}}$ therefore equals $F_{\mathrm{m}}-F_{0}$.

According to Genty et al. (1989) the effective quantum efficiency of charge separation (i.e. the effective quantum efficiency of PSII) in actinic irradiance is

$$
\Delta F / F_{\mathrm{m}}^{\prime}=\left(F_{\mathrm{m}}^{\prime}-F_{\mathrm{s}}\right) / F_{\mathrm{m}}{ }^{\prime}
$$


where $F_{\mathrm{s}}$ is the steady-state fluorescence and $F_{\mathrm{m}}{ }^{\prime}$ the maximum fluorescence after a saturating pulse when measured in the light.

$\Delta F / F_{\mathrm{m}}{ }^{\prime}$ can be used to calculate the linear rate of photosynthetic electron transport (ETR) as of a single active PSII unit (Genty 1989, Hofstraat et al. 1994):

$$
\mathrm{ETR}=\Delta F / F_{\mathrm{m}}{ }^{\prime} \cdot \mathrm{PFD} \cdot a^{*} \text { PSII }
$$

where $a^{*}$ PSII is the optical cross section of PSII. The product of PFD and $a^{*}$ PSII equals the amount of absorbed irradiance by a PSII unit. ETR is called $J_{\mathrm{e}}$ by Hofstraat et al. (1994). As we could not measure $a^{*}$ PSII relative ETR was calculated as $\Delta F / F_{\mathrm{m}}{ }^{\prime} \cdot \mathrm{PFD}$. The ETR light response curves were fitted to the Platt \& Jassby (1976) hyperbolic tangent model and from the fit of the maximum rate of ETR $\left(\mathrm{ETR}_{\max }\right)$, the initial slope $\left(\alpha_{\mathrm{ETR}}\right)$ and the light saturation parameter $\left(E_{\mathrm{kPAM}}=\right.$ $\mathrm{ETR}_{\text {max }} / \alpha_{\mathrm{ETR}}$ ) were calculated. We did not measure the minimum fluorescence in the light-adapted state $\left(F_{0}{ }^{\prime}\right)$ in between the light steps. Non-photochemical processes like heat dissipation of absorbed light by the xanthophyll cycle (Ruban \& Horton 1995) will decrease the PSII cross section, and will thus lower both the $F_{\mathrm{m}}$ as well as the $F_{0}$. In order to check this we used the $F_{0}$ immediately upon transfer to the dark (without far red light) at the end of the $P$ - $E$ curve as a measure of $F_{0}{ }^{\prime}$.

Carbon uptake: The procedure to obtain the $P$-E curves and photosynthetic parameters was described in detail in Barranguet et al. (1998). Microphytobenthic potential production, calculated as ${ }^{14} \mathrm{C}$ bicarbonate uptake, was measured in a photosynthetron (Lewis \& Smith 1983) with 7 light intensities from 0 to $1536 \mu \mathrm{mol}$ $\mathrm{m}^{-2} \mathrm{~s}^{-1}$.

The incubation procedure followed that of MacIntyre \& Cullen (1995) with small modifications. The superficial $\mathrm{mm}$ of 2 sediment cores was diluted in $50 \mathrm{ml}$ of filtered seawater, and aliquots of $2.5 \mathrm{ml}$ were taken while the sample was agitated, producing an homogeneous slurry. The aliquots were placed in glass scintillation vials and $50 \mu \mathrm{l}$ of $\mathrm{NaH}^{14} \mathrm{CO}_{3}$ (Amersham) was added to each sample to a final activity of $18.5 \mathrm{kBq}$ $\mathrm{ml}^{-1}$. The samples were incubated at in situ temperatures. Carbon incorporation was stopped after $30 \mathrm{~min}$ with $100 \mu \mathrm{l}$ of concentrated $\mathrm{HCl}$, which removes all the non-incorporated inorganic carbon, as proved by dark and control incubations. The samples were counted using a Beckman LS 5000TD scintillation counter including quenching correction, after addition of $17.5 \mathrm{ml}$ of Dynagel (Baker Analyzer Reagent).

The values of production for each light intensity (2 replicates), expressed per unit area $\left(\mathrm{mg} \mathrm{C} \mathrm{m} \mathrm{m}^{-2} \mathrm{~h}^{-1}\right)$, were normalized for chlorophyll units and fitted according to Platt \& Jassby (1976) to calculate the photosynthetic parameters $\alpha^{B}, P_{\max }^{B}$ and $E_{\mathrm{k}} \cdot \alpha^{B}$ is the initial slope of the $P$ - $E$ curve (photosynthesis rate at sub-saturating light, in $\mathrm{mg} \mathrm{C} \mathrm{mg} \mathrm{chl} a^{-1}\left(\mu \mathrm{mol} \mathrm{m}{ }^{-2}\right.$ $\left.\left.\mathrm{s}^{-1}\right)^{-1} \mathrm{~h}^{-1}\right) . P_{\text {max }}^{B}$ is the maximum photosynthetic capacity at saturating irradiances (mg C mg chl $\left.a^{-1} \mathrm{~h}^{-1}\right) . E_{\mathrm{k}}$ $\left(\mu \mathrm{mol} \mathrm{m}{ }^{-2} \mathrm{~s}^{-1}\right.$ ), the light saturation parameter, is calculated as $P_{\max }^{B} / \alpha^{B}$ and is often used as a photoacclimation index.

To calculate production for the whole photic zone, irradiance attenuation between 400 and $700 \mathrm{~nm}$ in the first $\mathrm{mm}$ of sediment was measured with reconstituted sediment as in MacIntyre \& Cullen (1995), assuming an exponential decrease of light intensity in the sediments, according to the formula:

$$
E_{\mathrm{z}}=E_{0} \cdot \mathrm{e}^{-k \cdot \mathrm{z}}
$$

where $k$ is the attenuation coefficient $\left(\mathrm{mm}^{-1}\right)$ and $z$ the depth (mm).

Incident light intensity was averaged for the $1.5 \mathrm{~h}$ period between each measurement, and with $3 P$-E curves 3 estimates of carbon fixation were obtained per sampling day.

Production was calculated at each depth $\left(P_{z}\right)$ with a resolution of $0.1 \mathrm{~mm}$ as:

$$
P_{z}=\operatorname{chl} a \cdot P^{B} \max \left(1-\mathrm{e}^{\left(\alpha^{B} \cdot E_{z} / P_{\max }^{B}\right)}\right)
$$

The production at each layer was added up for the whole photic zone, assuming a constant chl a content with depth in the photic zone. Two-way ANOVAs were performed to test the significance of the short-term (hours) and monthly variations of chl a contents, primary production, and photosynthetic parameters $\left(P_{\max }^{B}, \alpha^{B}\right.$ and $\left.E_{\mathrm{k}}\right)$ at Molenplaat Stns A and B in the Westerschelde estuary.

\section{RESULTS}

\section{$F_{0}$ versus chlorophyll}

The PAM settings were changed at each sampling date, according to the different sediments and algal concentrations; subsequently, all $F_{0}$ values were rescaled to the same settings, using pure chl a for the calibration. There was good agreement between the actual chl a concentrations measured $\left(\mathrm{r}^{2}=0.54, \mathrm{p}<\right.$ 0.01; Fig. 2A) from the ${ }^{14} \mathrm{C}$ production cores and the $F_{0}$ values. However, the ${ }^{14} \mathrm{C}$ cores were taken 3 times during emersion, while the core for PAM measurements was the same during the whole emersion at 1 day. Between measuring periods, the core was exposed to a constant irradiance of $460 \mu \mathrm{mol} \mathrm{m} \mathrm{m}^{-2} \mathrm{~s}^{-1}$. During cold periods, the sediment temperature was controlled by pumping seawater through a coil surrounding the core. If the behaviour in the field would be different than in the PAM core (e.g. with respect to vertical migration) a better relationship might be obtained 


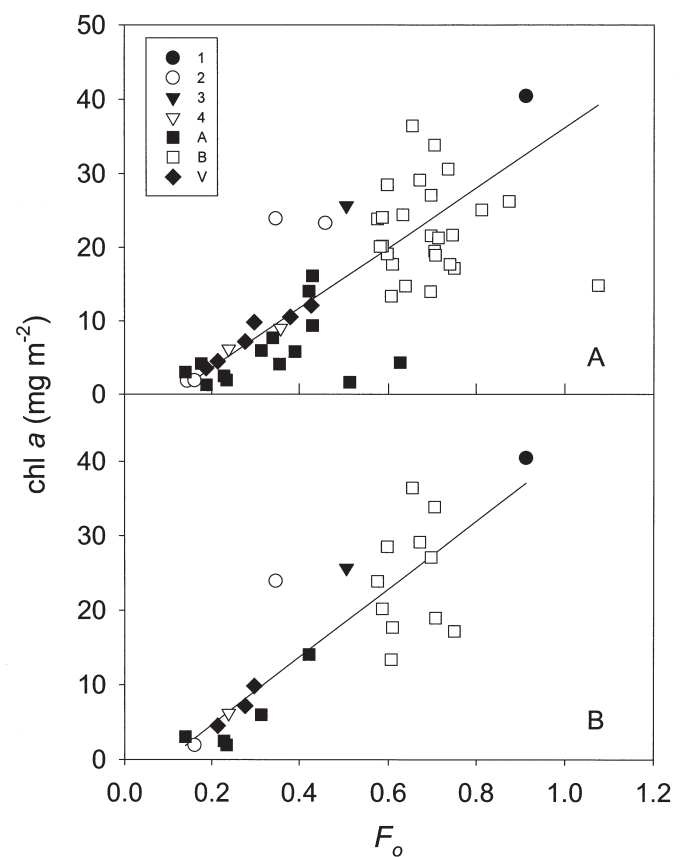

Fig. 2. Relationship between minimal fluorescence $\left(F_{0}\right)$ and chlorophyll a (A) for all stations and sampling times and (B) for the first measurements taken at the sampling days. In the latter case the algae were exposed for a shorter time to possible high incident irradiances (i.e. $\gg E_{\mathrm{k}}$ )

when only the first sampling points are compared. Indeed, the regression improved when only the cores taken at the beginning of emersion for ${ }^{14} \mathrm{C}$ were compared to the first $F_{0}$ measured, because they were taken simultaneously $\left(r^{2}=0.73\right.$; Fig. $\left.2 B\right)$.

\section{Photosynthetic parameters}

Two-way ANOVAs for data at Stns A and B showed, for both ${ }^{14} \mathrm{C}$ and PAM data, that on a seasonal scale the differences within the same day in the photosynthetic parameters were not significant, but that the oscillations between months were significant. No differences existed in maximum rates of photosynthesis $\left(\mathrm{ETR}_{\max }\right.$ or $\left.P_{\max }^{B}\right)$, light utilisation efficiency $\left(\alpha^{B}\right)$ or the light saturation intensities $\left(E_{\mathrm{k}}\right)$ between the different stations (Fig. 3).

ETR $_{\max }$ values varied generally between 100 and 600 (Fig. 3A), and the median value was quite similar for all stations (300 to 320). Values higher than 400 are most likely fitting artifacts as saturation of ETR was not always achieved at the highest irradiance used. Maximum rates of carbon fixation $\left(P_{\max }^{B}\right)$ varied between 2 and $18 \mathrm{mg} \mathrm{C} \mathrm{mg} \mathrm{chl} a^{-1} \mathrm{~h}^{-1}$ (Fig. 3B). The variation in both parameters could substantially change during a month, and was partly caused by daily changes in inci-

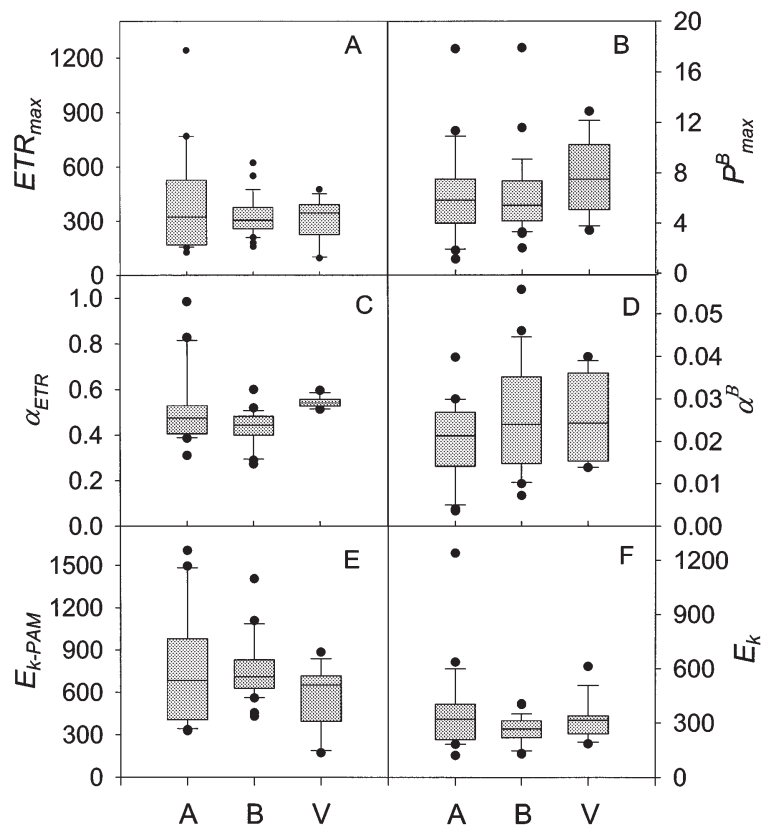

Fig. 3. Box whisker plots showing photosynthetic parameters. (A, C, E) PAM data, (B, D, F) C fixation data. (A, B) Maximum rates of photosynthesis. (C, D) Maximum light utilisation efficiency $\alpha$ (initial slope $P-E$ curve). (E, F) Light saturation parameter $E_{\mathrm{k}}$. A: Molenplaat Stn A. B: Molenplaat Stn B. V: Vondelingenplaat Stn V

dent irradiance (photoacclimation; Kromkamp et al. 1998) and might be related to different sediment characteristics. In winter, due to lower temperatures, both parameters were lower. The differences between the stations were not significant.

Most values for $\alpha^{B}$ lay between 0.015 and $0.035 \mathrm{mg} \mathrm{C}$ $\mathrm{mg} \mathrm{chl} a^{-1}\left(\mu \mathrm{mol} \mathrm{m}{ }^{-2} \mathrm{~s}^{-1}\right)^{-1} \mathrm{~h}^{-1}$ (Fig. 3D). The scatter in $\alpha$ from the PAM measurements was less than for $\mathrm{C}$ fixation (Fig. 3C,D). A clear seasonal cycle was absent, as might be expected from a process which is regulated by the change to absorb available photons. As a result, $E_{\mathrm{k}}$ showed the same seasonal trend as the ETR $\mathrm{ERax}_{\text {(not }}$ shown). $E_{\mathrm{k}}$ values for $\mathrm{C}$ fixation varied generally between 200 and $400 \mu \mathrm{mol} \mathrm{m}{ }^{-2} \mathrm{~s}^{-1}$, whereas the $E_{\mathrm{k}}$ for ETR was higher and lay between 400 and $1000 \mu \mathrm{mol} \mathrm{m}^{-2} \mathrm{~s}^{-1}$ (Fig. 3E,F).

When the data of all sediment types were pooled together, no correlation between photosynthetic parameters $\left(P_{\max }^{B}, \alpha^{B}\right.$ and $\left.E_{\mathrm{k}}\right)$ determined by both methods could be found. Plotting only the initial measurements did not improve the picture, as it did for $F_{0}$.

Such absence of correlation is not surprising. The ${ }^{14} \mathrm{C}$ data considered all the optical depths of sediments, different at each station, but also changing during the year at the Molenplaat (Barranguet et al. 1998), the PAM measures only the first 100 to $200 \mu \mathrm{m}$. This however does not mean that there is no relationship be- 
tween linear ETR and C fixation. This relationship was investigated for each sampling site individually and is presented below.

\section{Comparison between ETR and C fixation}

When the rate of chlorophyll-specific $C$ fixation was plotted as a function of relative ETR, it appeared that at higher rates of photosynthesis the linear relationship disappeared for sediments at Molenplaat Stn B (Fig. 4A). In spring (February, March and April) this occurred at irradiances above $200 \mu \mathrm{mol} \mathrm{m} \mathrm{m}^{-2} \mathrm{~s}^{-1}$, whereas later in the year this occurred at irradiances exceeding 350 to $400 \mu \mathrm{mol} \mathrm{m} \mathrm{m}^{-2} \mathrm{~s}^{-1}$. However, the relationship was always linear at irradiances below the $E_{\mathrm{k}}$ for carbon fixation. The regression coefficient $(a)$ of the linear part of the curve gives an indication of the efficiency of the photosynthetic apparatus, and can be used to calculate $C$ fixation at irradiances up to $E_{\mathrm{k}}$ :

$$
P^{B}=a \cdot \text { ETR }
$$

This can be rewritten as:

$$
P^{B}=\mathrm{ETR} \cdot a^{*}{ }_{\mathrm{PSII}} \cdot n_{\mathrm{PSII}} \cdot \Phi_{\mathrm{e}}^{-1}
$$

where $a^{*}{ }_{\text {PSII }}$ is the optical cross section of PSII, $n_{\text {PSII }}$ the number of PSIIs mg chl $a^{-1}$, and $\Phi_{\mathrm{e}}$ the electron requirement for C fixation (i.e. the amount of electrons produced by PSII necessary to fix $1 \mathrm{CO}_{2}$ ). Thus the regression coefficient equals $a^{*}{ }_{\mathrm{PSII}} \cdot n_{\mathrm{PSII}}$. $\Phi_{\mathrm{e}}^{-1}$. We call a the ETR efficiency for C fixation (EE).

As during a $P$-E curve the number of PSII mg $\mathrm{chl}^{-1}$ will not change (assuming that no structural photoinhibition occurred, which was not apparent in both the ETR as well as in the $\mathrm{C}$ fixation rates at high irradiances), a change in the slope of the curves will most likely be due to a change in the electron transport efficiency, and/or due to a change (decrease) in $a^{*}$ psII. As can be seen in Fig. 5A, EE varies between 0.04 and 0.06 most of the time, and the seasonal average for Stn B was $0.057 \pm 0.013$.

The sandy Molenplaat Stn A (Fig. 4B), and the Ecoflat Stns 1, 2, 3 and 4 (Fig. 4C) showed a better relationship between specific carbon uptake $\left(P^{B}\right)$ and ETR. Especially at the Ecoflat stations, the relationship was generally linear up to the highest irradiances investigated $\left(1000 \mu \mathrm{mol} \mathrm{m} \mathrm{m}^{-2} \mathrm{~s}^{-1}\right)$. Notice that Ecoflat Stn 1 and especially 2 are more cohe- sive (contain more silt) than Stn B. Hence, whether the non-linear relationships between ETR and $C$ fixation at saturating irradiances (for $\mathrm{C}$ fixation) are related to sediment characteristics is unclear at present. The data set is too small to detect seasonal changes for the Ecoflat stations, where all the measurements were taken in summer. Non-linear relationships (above $E_{\mathrm{k}}$ for $\mathrm{C}$ fixation) were observed at $\mathrm{Stn} \mathrm{A}$ in winter, but in summer complete linear relationships were observed. For Stn A, we could not find a significant negative correlation between $E_{\mathrm{kPAM}}$ and $E_{\mathrm{k}^{14} \mathrm{C}}$ and temperature, but the data set does not contain enough values with low temperatures, although there is a negative trend $(\mathrm{r}=$ $-0.41)$. The difference between $E_{\mathrm{k}}$ from both methods is greater at Stn A than the differences found at Stn B.

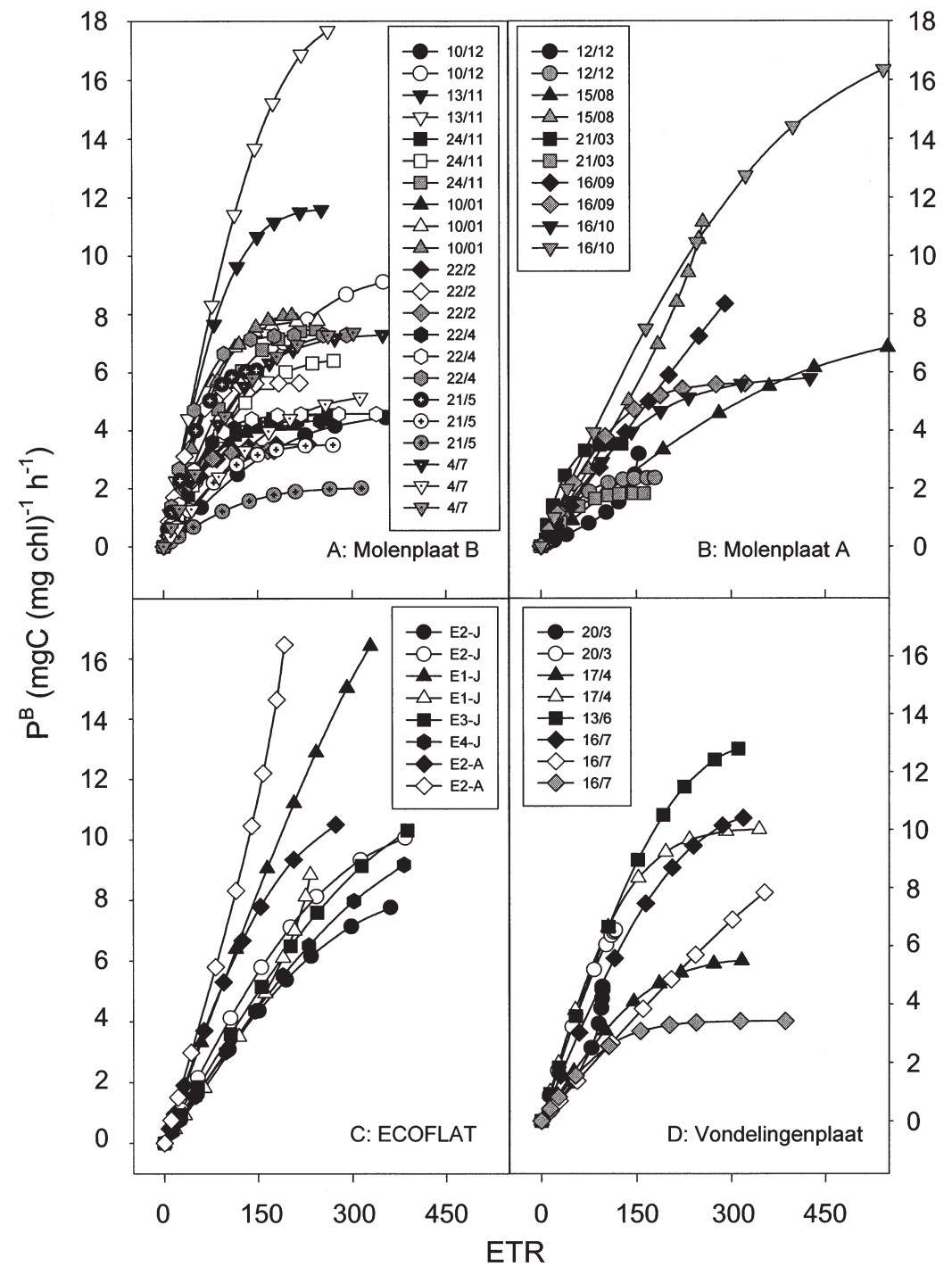

Fig. 4. C fixation rates as a function of ETR at the 4 different sampling sites (A to D). Closed symbols are the first measurements taken (late morning), open symbols the second measurement (early afternoon), and grey symbols are the third sample taken (mid afternoon) during the same low tide 


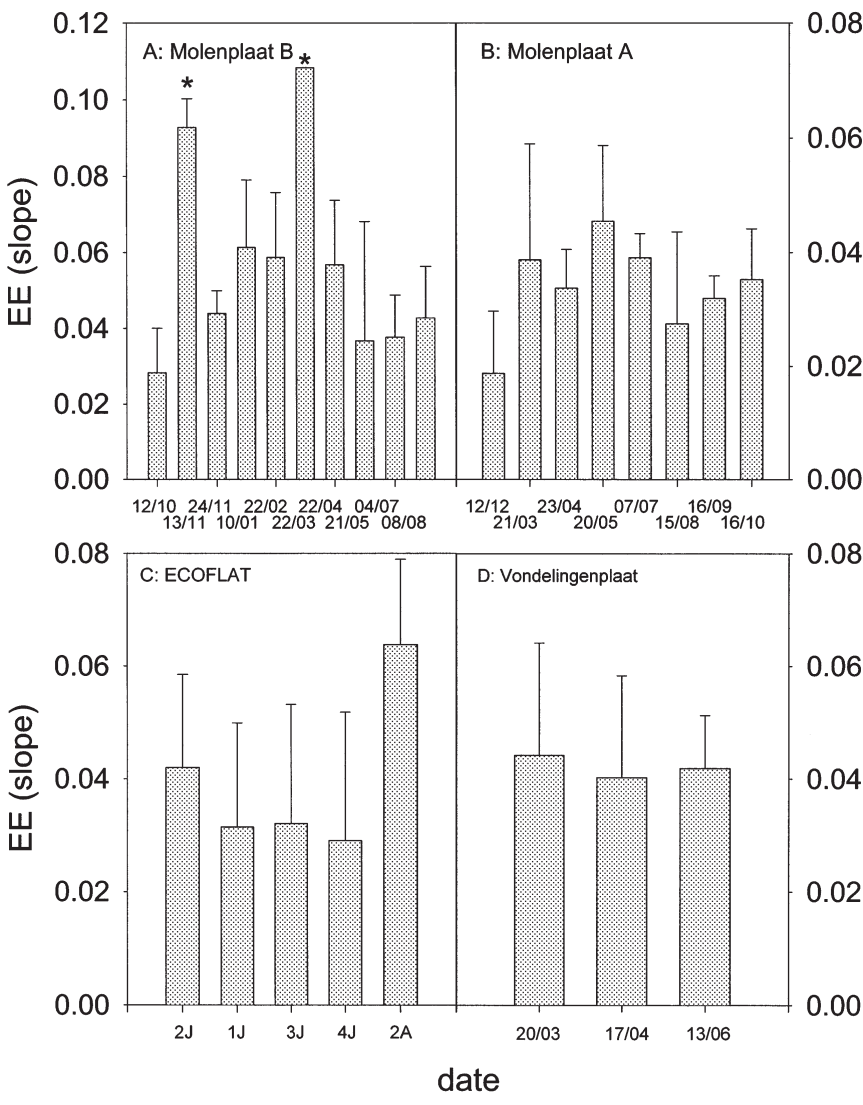

Fig. 5. Regression coefficient EE (slope of linear part of the ETR vs C fixation curve) at several sampling days (d/mo). Error bars give indication of variability (standard error or deviation from the mean) from 2 to 3 measurements during 1 tidal cycle. The Ecoflat Stns 1 to 4 were visited in June only, apart from Stn 2, which was visited in August as well (Fig. 5C). Asterisks denote significant higher value of EE $(\mathrm{p}<0.05)$

Both complete linear relationships, as well as deviations from linearity between ETR and C fixation at high irradiances, were found at Vandelingenplaat Stn V in the Oosterschelde estuary. The degree of non-linearity was, however, not as pronounced as at Stn B in the Molenplaat. Similar slopes were found for the other stations: EE varied between 0.015 and 0.04 (Fig. 5D).

The average regression coefficient (EE) for Molenplaat Stn B was $0.057 \pm 0.026$, for the Ecoflat stations $0.042 \pm 0.016$, for Stn A $0.034 \pm 0.012$ and for the Vondelingenplaat Stn V $0.042 \pm 0.015$ (Fig. 6). The difference in regression coefficients between Stns A and $\mathrm{B}$ was significant $(t$-test, $\mathrm{p}<0.003)$. The difference between the Ecoflat stations and Stn B ( $p=0.103)$ and between the Ecoflat stations and A and Vondelingenplaat was not significant $(\mathrm{p}=0.092$ and 0.088 respectively). EE from the Vondelingenplaat Stn V samples did not differ significantly from any of the other sites.
Thus, despite the fact that EE of Stn A was lower than EE at Stn B (and that photosynthesis is thus less efficient at Stn A) the fact that the differences in EE from both Stns A and B compared with the other stations are not significant seems to indicate that observed differences in EE between Stns A and B are probably not significant either.

\section{Integrated primary production}

In order to compare rates of areal primary production, we calculated rates of photosynthesis with depth. From the measured attenuation coefficient we calculated the irradiance with depth, and we assumed for the sake of calculation a homogeneous distribution of chl a with depth. From the measured incident irradiance and the $C$ fixation parameters $P_{\max }^{B}$ and $\alpha^{B}$, the total $\mathrm{C}$ fixation with depth was calculated. ETR rates were converted to $\mathrm{C}$ fixation rates as follows:

$$
\mathrm{C} \text { fixation }=\mathrm{chl} \mathrm{a} \cdot \mathrm{EE} \cdot \mathrm{ETR}
$$

ETR was calculated from the maximum rate of ETR and the initial slope of an ETR versus light curve. For each station we used the same average value of all EE values (0.043); hence we assumed that the conversion from PAM obtained rates of electron transport to chlorophyll-specific rates of $\mathrm{C}$ fixation did not vary throughout the season. An example of a depth profile is given in Fig. 7. In this example, we see that production rates based on ETR measurements are lower than primary production based on $\mathrm{C}$ fixation, whereas in the afternoon both methods gave the same production rates. Summation of photosynthetic $C$ fixation at each depth gives the total primary production in the sediment.

As could be expected based on the non-linear relationships between $\mathrm{C}$ fixation and ETR in high light at

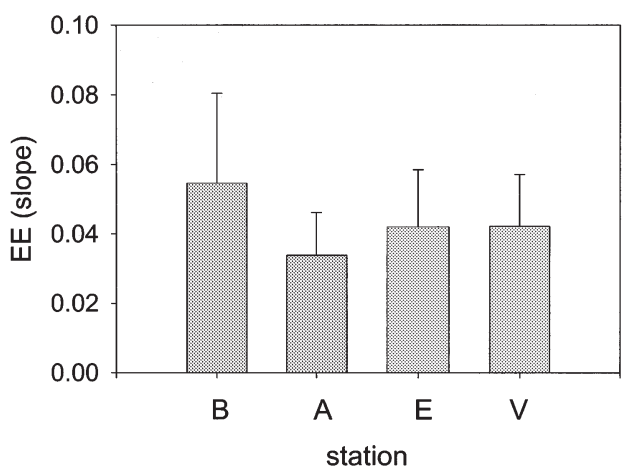

Fig. 6. Average values for the electron requirement EE (i.e. the conversion factor needed to convert ETR into $P^{B}$ ). B: Molenplaat Stn B; A: Molenplaat Stn A; E: Ecoflat sampling stations on the Molenplaat; V: Vondelingenplaat Stn V 


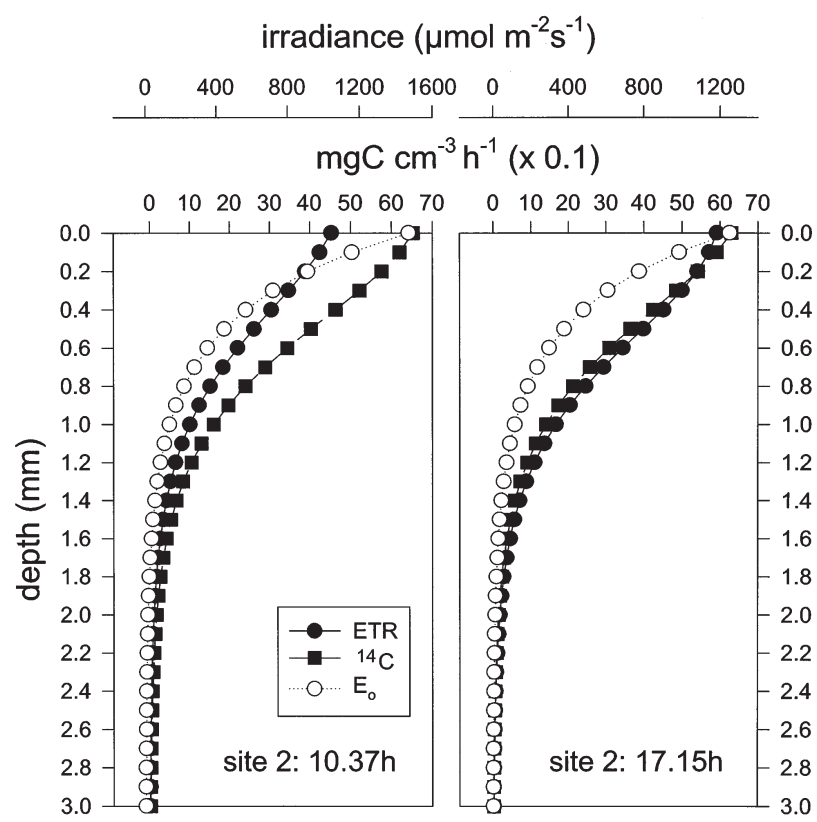

Fig. 7. Example of 2 depth profiles of irradiance (O) and C fixation based on PAM measurements $(\bullet)$ or ${ }^{14} \mathrm{C}$ fixation (ם) taken at the same day but at different times during low tide

Stn B, the primary productivity estimates differed considerably, although ETR was seldom higher than $200 \%$ or lower than $50 \%$ of the C fixation rate (Fig. 8).

For Molenplaat Stn A the agreement was fairly good (Fig. 9). Only on 2 occasions was there a large mismatch: in December ETR overestimated the C fixation

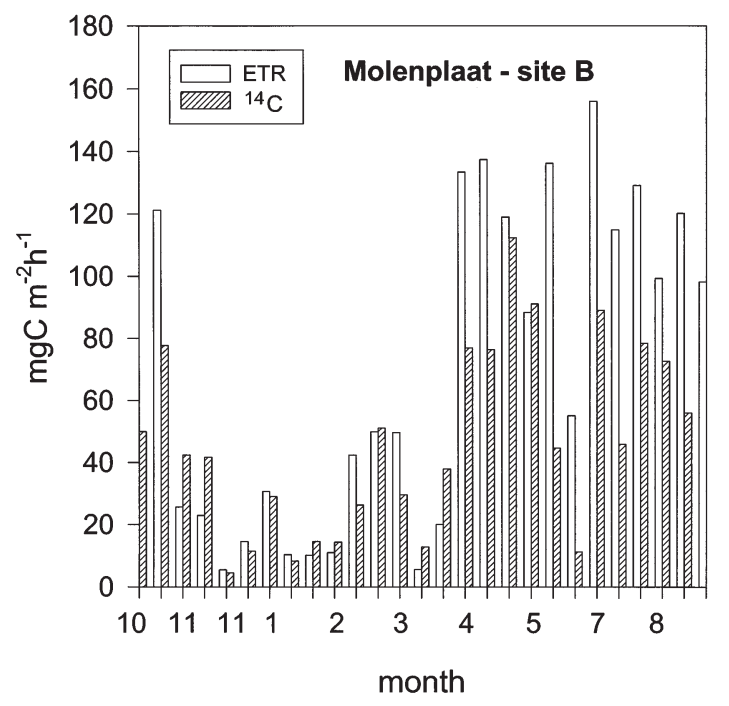

Fig. 8. Comparison of primary production based on ETR (open bars) and $\mathrm{C}$ fixation (hatched bars) measurements for Molenplaat Stn B. The site was visited twice during one tidal cycle in October and twice on 2 dates in November 1995, and 3 times during a tidal cycle in the other months

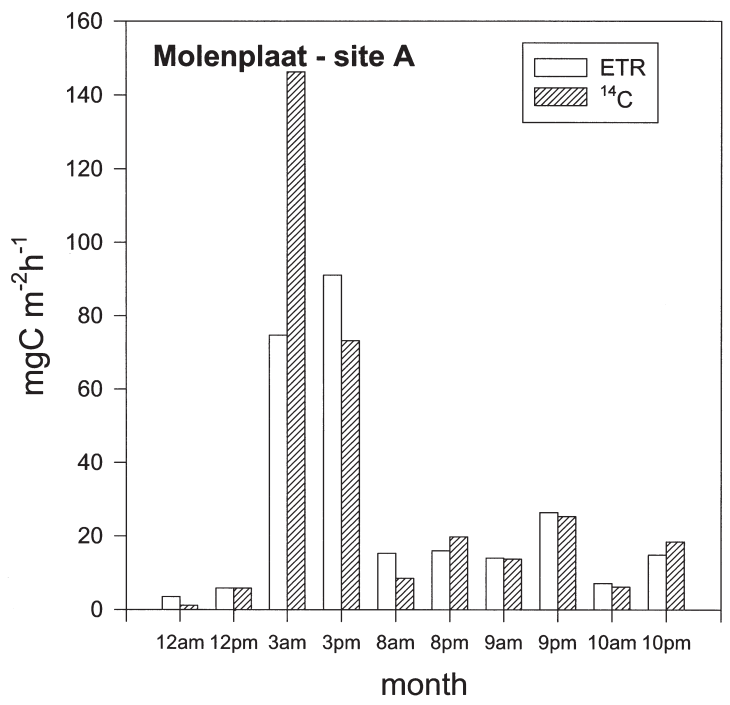

Fig. 9. Comparison of primary production based on ETR and $\mathrm{C}$ fixation measurements for Molenplaat Stn A. At each date the first measurement was taken in late morning (am) about $1 \mathrm{~h}$ before low tide. The second measurement was performed near the end of the same emersion period

by a factor of 2 . Production rates were very low at that date though, so measuring errors could be important. The second core taken that day gave identical estimates of primary production. ETR underestimated the C fixation of the first core taken in March. In August ETR also overestimated $\mathrm{C}$ fixation for the first measurements, but later that day the estimates were similar, with a slightly higher estimate for $\mathrm{C}$ fixation.

At Ecoflat Stns 1 to 4, a very good agreement was obtained for 5 out of 6 measurements (Fig. 10). At Stn 2 the ETR-based estimate in the morning underestimated the production relative to the $\mathrm{C}$ fixation by about $35 \%$.

As Molenplaat Stn A and the Ecoflat stations showed generally linear relationships between ETR and C fixation, the occasional discrepancy between the estimates was most likely due to some diurnal variation in photosynthesis or patchiness.

Comparisons for Vondelingenplaat Stn $\mathrm{V}$ in the Oosterschelde (Fig. 11) were much better than for Stn B, but not as good as for Stn A and the Ecoflat stations. On average, the ratio of C:ETR was 0.91 for the Ecoflat stations, 0.88 for Molenplaat Stn A, 0.65 for Molenplaat Stn B and 0.76 for Vondelingenplaat Stn V. Recalculation of the data for the latter 2 stations, assuming that above $E_{\mathrm{k}}$ increases in ETR will not lead to higher rates of $\mathrm{C}$ fixation, causes the ratio to change to 0.76 and 0.95 respectively. Hence, apart from Stn B, the overall agreement between both methods was quite good, despite the fact that the PAM-derived primary production estimate was based on a surface mea- 


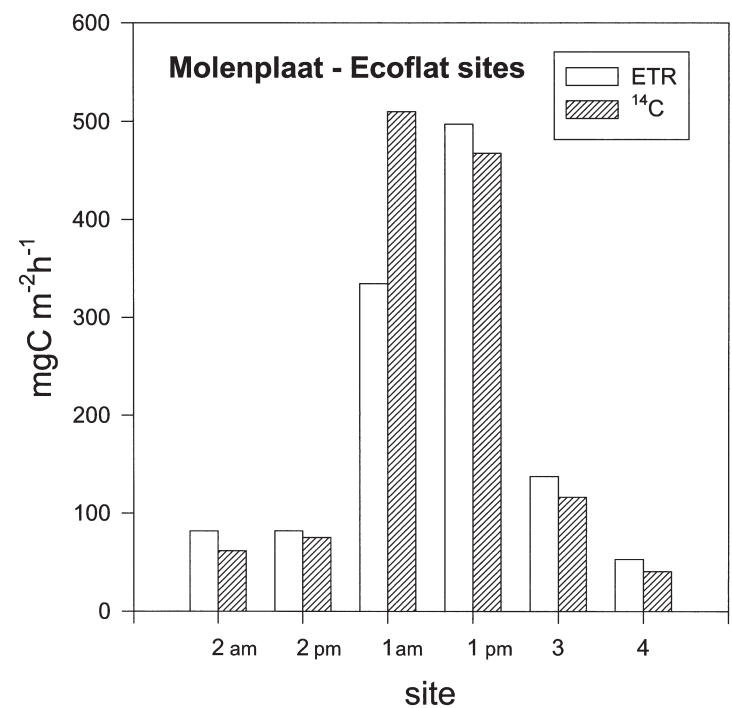

Fig. 10. Comparison of primary production based on ETR and C fixation measurements for Ecoflat Stns 1 to 4 . Stns 1 and 2 were sampled twice during the same tidal cycle

surement. It is clear from Fig. 12, where the production estimates of both methods are plotted against each other, that there is no significant difference between the stations.

\section{DISCUSSION}

Richardson (1991) demonstrated that when different laboratories were given the same samples, very significant differences in $\mathrm{C}$ fixation based production esti-

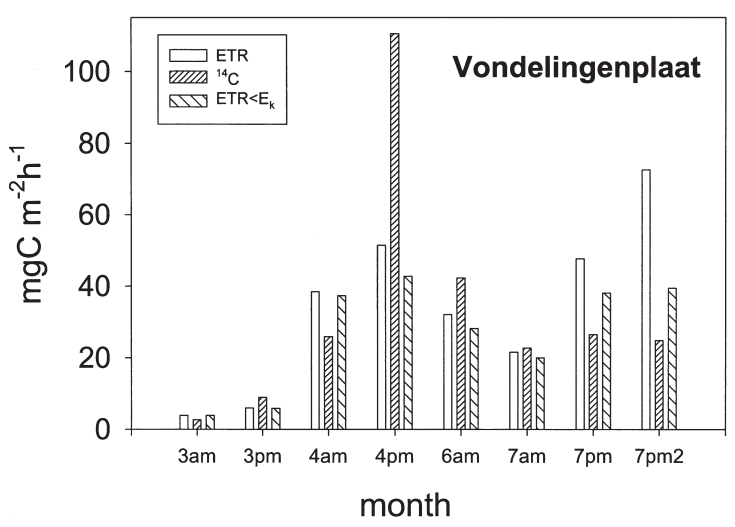

Fig. 11. Comparison of primary production based on ETR and C fixation measurements for Stn V. In order to reduce the possible overestimation of $\mathrm{C}$ fixation by ETR when non-linearity between ETR and C fixation occurred, we also calculated the ETR-based $C$ fixation rates under the assumption that above $E_{\mathrm{k}}$ for C fixation ETR would not increase. This improved the agreement between the 2 methods in July

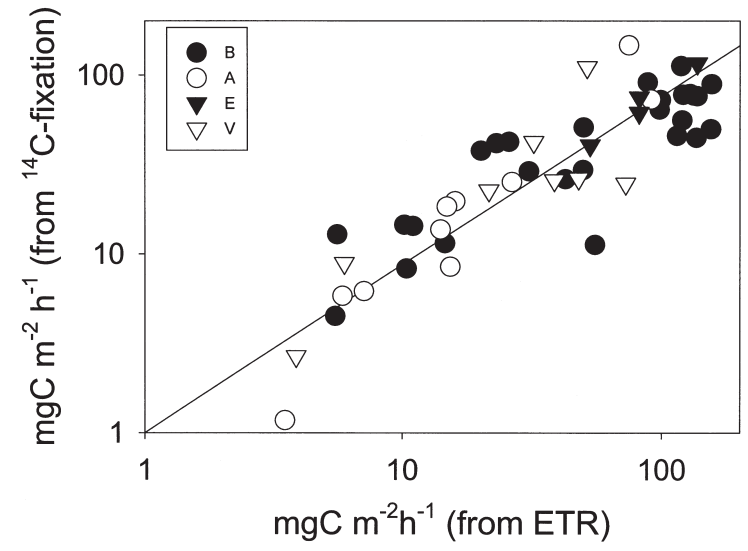

Fig. 12. Plot of hourly production rates based on C fixation as a function of ETR. As can be seen, all estimates lie along the same line (slope $=0.94, r^{2}=0.79$ ), indicating that no significant difference exists in conversion factor (EE) between the different sampling sites

mates occurred when they used their own or standard methods. It is therefore interesting to note that the variation in estimates of the maximum $\alpha^{B}$ is much smaller when estimated by the PAM technique than when estimated from $\mathrm{C}$ fixation measurements (Fig. 3C,D). This suggests that the PAM method is more robust and potentially better suited for intercomparison purposes. On the other hand, the smaller variance of $\alpha_{\text {ETR }}$ might be a statistical artifact as $\alpha_{\text {ETR }}$ is only dependent on variance in $\Delta F / F_{\mathrm{m}}$ ' only, whereas $\alpha^{B}$ is dependent on variance in both irradiance and photosynthesis.

\section{Estimation of $\operatorname{chl} a$ from $F_{0}$ values}

In dark-adapted plants, most of the $F_{0}$ originates from the chl a associated with PSII (Krause \& Weis 1991, Büchel \& Wilhelm 1993). Therefore, a good correlation between $F_{0}$ and chl a can be expected. This principle is often succesfully used in oceanography with a fluorometer attached to a CTD, despite the fact that the irradiance of these fluorometers is often actinic. Geel (1997) has indeed found a good relationship between $F_{0}$ and chl a for marine phytoplankton in mesocosms simulating the coastal North Sea. The relationship between chl $a$ and $F_{0}$ for the microphytobenthos shown in Fig. 2 was obtained from different sampling stations. Despite the diversity of sediments considered, with different algae (mainly diatoms at all stations) and optical depths, $F_{0}$ appeared to be a good indicator of chlorophyll differences in concentrations between stations. Stn B, with muddy sands, showed the poorest correlation between $F_{0}$ and chl $a$. At this station a high fraction of vertically migrating epipelic 
diatoms was present. Ecoflat Stns 1 and 2 were also very silty, but these were only measured in summer once and twice respectively. Furthermore, it is very difficult to accurately slice off $1 \mathrm{~mm}$ of sediment, especially at the silty sites. This too might have contributed to the scatter at Stn B, where the silt content changes throughout the year (P. Herman pers. comm.). Adding to this is a possible scale problem: we sampled a depth of $1 \mathrm{~mm}$, but the 'measuring depth' of the PAM is approximately $150 \mu \mathrm{m}$ (Kromkamp et al. 1998). Thus we implicitly assume that, within our slice, chlorophyll concentration is either evenly distributed or that it always shows the same relationship with depth. Vertical microprofiles of chlorophyll with depth show that this is not always the case (Wiltshire et al. 1998, de Brouwer pers. comm.). Furthermore, the PAM method uses a red LED (light emitting diode) $\left(\lambda_{\max }=650 \mathrm{~nm}\right)$ as modulated measuring light. The absorption cross section of PSII for this wavelength is dependent on the pigment composition of the algae: cyanobacteria will absorb this better than diatoms. Thus at a similar measuring light intensity, the fluorescence yield of cyanobacteria will be higher than that of an equal chlorophyll biomass of diatoms. Thus, a change in species composition with different pigment types might also contribute to the scatter in the relationship between $F_{0}$ and chl $a$.

Another reason for the fact that the relationship between $F_{0}$ and chlorophyll was better for the first samples taken might be the fact that the dark adaptation period was not sufficient to get relaxation of all nonphotochemical quenching processes, especially during very sunny days. The cells at the surface might have been exposed to high irradiances for a prolonged period and this might induce some chronic photoinhibition, which did not disappear during the dark adaptation period used, although we showed before that at some dates the microphytobenthos at the Molenplaat hardly showed any photoinhibition after prolonged exposure to high irradiances, possibly because of vertical 'micro-migration', where cells leaving the surface are replaced by new ones coming from below (Kromkamp et al. 1998). The capacity to do this is of course dependent on species composition, because not all species show active vertical migration.

\section{Photosynthetic parameters and primary production rates}

For the Molenplaat, we described earlier that maximum rates of photosynthesis varied throughout the seasons and showed signs of photoacclimation, whereas $\alpha^{B}$ did not show any seasonal variation (especially when measured with the PAM fluorometer) (Bar- ranguet et al. 1998, Kromkamp et al. 1998). Similar results were obtained by us from Stn V at the Vondelingenplaat, an intertidal flat in the Oosterschelde, which is generally low in nutrients (Wetsteyn \& Kromkamp 1994). The fact that similar photosynthetic parameters were obtained indicates that nutrient limitation of the microphytobenthos was probably not important. This is corroborated by the fact that $F_{\mathrm{v}} / F_{\mathrm{m}}$ values were generally high. Low $F_{\mathrm{v}} / F_{\mathrm{m}}$ values indicate nutrient limitation (Kolber et al. 1988, 1990, 1994, Flameling 1998, Kromkamp \& Peene 1999) although this might also be caused by chronic photoinhibition, a situation to which microphytobenthos might easily be induced in benthic algae exposed to the surface. However, effective quantum efficiencies were generally high, even at high irradiances as determined in the $P-E$ curves, demonstrating that the microphytobenthos are well adapted to high irradiance conditions.

In general, we found no significant correlation for $P_{\text {max }}^{B}, \alpha^{B}$ or $E_{\mathrm{k}}$ between the PAM and $C$ fixation methods. Hartig et al. (1998) also compared estimates of photosynthesis based on $\mathrm{C}$ fixation and PAM fluorescence. They found a relationship only for $P_{\max }^{B}$ they performed their measurements on the motile fraction of the microphytobenthos only, and carried the PAM and $C$ fixation measurements out on the same sample (a slurry). For most stations, they observed a linear relationship between ETR and C fixation, although at some stations their fluorescence-based rate of photosynthesis overestimated the $\mathrm{C}$ fixation rate at high irradiances, just like in our measurements. We observed this more frequently then they did, but this might be due to the fact that we have a much larger data set, spanning all seasons. In order to quantify ETR, Hartig et al. (1998) multiplied ETR with the chlorophyll-specific optical cross section. However, in order to obtain quantitative estimates of $\mathrm{C}$ fixation, relative rates of ETR should be multiplied by the optical cross section of PSII ( $\left.a^{*}{ }_{\text {PSII }}\right)$, the number of PSII per mg chl $a$ and $\Phi_{\mathrm{e}}^{-1}$ (Eq. 7). Our conversion factor EE is the product of these 3 parameters, and varies between 0.03 and 0.05 (Fig. 6), which is 3 to 8 times as high as the optical cross section measured by Hartig et al. (1998). Our $P_{\max }^{B}$ values were also 3 to 10 times as high, but in the same range as found by others (Blanchard \& Cariou-Le Gall 1992, Blanchard \& Montagna 1992, MacIntyre \& Cullen 1995, 1996). These results suggest that the product of $a^{*}$ PSII $n_{\text {PSII }}$ and $\Phi_{\mathrm{e}}^{-1}$ co-varies with the chlorophyll-specific optical cross section. Our conversion factors for microphytobenthos were in the same range as those found for Oosterschelde phytoplankton, where median values for different stations ranged between 0.04 and 0.16 with median values of respectively 0.06 and 0.11 (Kromkamp \& Peene 1997). Recalculation of data published for a nutrient-replete culture 
of the green alga Chlorella pyrenoidosa (Kroon 1994), assuming a PQ-ratio of 1, gave EE values between 0.056 and 0.071 , i.e. in the same range as found by us for phytoplankton and microphytobenthos. Recalculation of data published by Geel et al. (1997) gave EE values varying between 0.007 and 0.02 for different marine phytoplankton species. Hartig \& Colijn (1996) reported EE values between 0.013 and 0.07 for different marine unicellular algae. Hence, there seems to be a species difference, as most of the above data were obtained with nutrient-replete cultures. The values may also vary with tidal exposure, as can be seen from the standard deviations in Fig. 5, which is a reflection of the change in EE during 1 tidal cycle. However, the differences during the day were not significant throughout the year (ANOVA, $\mathrm{p}>0.4$ ). This, and the high $F_{\mathrm{v}} / F_{\mathrm{m}}$ values, indicate that nutrient limitation $\left(\mathrm{CO}_{2}\right.$ especially) is probably not so important. There also seemed to be an absence in seasonality in the conversion factor of ETR to $P^{B}$. Only on 2 occasions was a significantly higher value of EE observed (Fig. 5A).

Changing sediment optics may have caused part of the absence of linearity above $E_{\mathrm{k}}$. ETR was calculated using the incident irradiance on the core surface. The optical depth for the PAM measurements was estimated to be approximately $150 \mu \mathrm{m}$ for Stn B (Kromkamp et al. 1998), but depends of course on the sediment type and the amount of algae. Hence, the average irradiance in the top layer of the sediment may be less than the incident irradiance. Another factor is that at Stn B the proportion of epipelic diatoms showing vertical migration is larger than at the more sandy sites. During the ETR measurements, upward vertical migration took place which may also decrease the average light intensity. Hence, if we could correct for this migration, the discrepancy between ETR and specific carbon fixation $\left(P^{B}\right)$ would probably be less.

Alternatively, we suggested in an earlier paper (Kromkamp et al. 1998) that microphytobenthos at the uppermost layer of the sediment showed a micromigration pattern: cells moving to the surface might replace cells at the surface. In this way the cells at the surface might escape high light stress by moving to slightly deeper layers (which may also be more $\mathrm{CO}_{2}$ rich), whilst being replaced by others. When this occurs, a feedback on the PSII quantum efficiency might not be so pronounced as during a 30 min exposure in the slurry incubations, resulting in higher rates of ETR compared to $\mathrm{C}$ fixation.

Changes in $a^{*}$ PSII and ETR (Eq. 7) might also be responsible for the absence of linearity above $E_{\mathrm{k} \text {. Geel }}$ (1997) demonstrated that $F_{0}$ is a measure of the product of the number of PSII and $a^{*}{ }_{\text {PSII }}$. Hence, an indication of a change in $a^{*}$ PSII can also be obtained by comparing $F_{0}{ }^{\prime}$ with $F_{0}$, i.e. with the fluoresence in the dark directly after completion of the $P$-E curve with the initial $F_{0}$ value. $F_{0}{ }^{\prime}$ lay between 0.9 and 1.7 of $F_{0}$. Non-photochemical quenching, often induced by the xanthophyll cycle, will decrease the photosynthetic efficiency. Together with state 1-state 2 transitions or spill-over (re-direction of absorbed light to PSI, Bennet 1983) this might decrease $a^{*}$ PSII. However, most values of $F_{0}{ }^{\prime}$ were larger than $F_{0}$, indicating that $a^{*}$ PSII did not change, but that it was influenced by upward vertical migration of diatoms during the measurement. It cannot be excluded though, that the increase in $F_{0}{ }^{\prime}$ due to vertical migration may have partly masked a decrease in $a^{*}{ }_{\text {PSII }}$.

Any process which will affect $\Phi_{\mathrm{e}}$ will influence the relationship between $C$ fixation and ETR. $\Phi_{\mathrm{e}}$ is the ratio of the effective quantum efficiencies of PSII to C fixation (Flameling \& Kromkamp 1998). A change in $\Phi_{\mathrm{e}}$ can be caused by an increased rate of dark respiration and alternative electron sinks, like the Mehler reaction or photorespiration (see Flameling \& Kromkamp 1998 for a discussion on these topics). Recently it has been postulated that temperate diatoms could take up nitrate in excess of growth demands, especially at lower temperatures and when light is in excess. The photosynthetic reduction of nitrate by nitrate reductase could in this way also serve as an alternative electron source to Rubisco, which has its maximum activity around $30^{\circ} \mathrm{C}$ (Lomas \& Glibert 1999). As the Westerschelde is rich in nitrate (average: $161 \mu \mathrm{M}$, in winter: 200 to $300 \mu \mathrm{M}$ ) a high rate of nitrate reduction might be an important alternative electron source, but this needs further investigation. All these alternative electron sinks allow PSII activity to continue, and provide protection to chronic photoinhibition, and thus serve as a buffer for the imbalance between energy generation and energy requirement for growth. To explore if increased nitrate reductase activity was a possible alternative electron sink for microphytobenthic diatoms, we calculated the ratio between $E_{\mathrm{kPAM}}$ and $E_{\mathrm{k}}$. Thus, we assumed that the ratio would increase if alternative electron sources would become more important. The ratio varied from month to month. For Stn $B$, indeed, there was a significant negative correlation $(\mathrm{r}=-0.656$, $\mathrm{p}<0.05)$ between the overestimation on $E_{\mathrm{kPAM}}$ and temperature, the largest differences between both methods were found when temperatures were around 4 to $6^{\circ} \mathrm{C}$, in accordance with Lomas \& Glibert's (1999) results for planktonic diatoms.

Sometimes primary production of microphytobenthos is estimated from chlorophyll only (de Jong \& de Jonge 1995). We also investigated this, but could not find any relationship between chlorophyll content and primary production (not shown). Similar results have been found for microphytobenthos in the German Wadden Sea area near the island of Sylt (D. Murphy 
pers. comm.). Cole \& Cloern (1987) estimated primary production in light-limited estuaries from a composite parameter (biomass $\times$ daily insolation $\times$ photic depth), and we oberved a good relationship between this parameter and phytoplankton production in some stations in the Westerschelde and Oosterschelde estuaries (Heip et al. 1995, Kromkamp et al. 1995). This relationship, however, does not hold for our microphytobenthos data (not shown).

It is not easy to explain the difference in photosynthesis between the more sandy sites and the silty Stn $\mathrm{B}$, but at the sandy sites it was speculated that the microphytobenthos was more adapted to high light, whereas at the silty site, the microphytobenthos were low light adapted (Barranguet et al. 1998). We did, however, find a good correlation for the Ecoflat stations. These stations were sampled in summer only, and the discrepancies between ETR and $P^{B}$ at Stn B were largest outside the main growing season. But part of the explanation might also be in the different optics of sand, and the lower proportion of epipelic (i.e. vertically migrating) diatoms or a different species composition (Sabbe 1997). It is clear that future research should investigate the light climate in more detail using optical microfibers (Kühl \& Jørgensen 1994, Kühl et al. 1994) and that vertical microprofiles of PAM measurements should be made in conjunction.

\section{Conclusions}

We investigated the possibility to estimate total primary production from surface-based PAM estimates. In the calculations, we assumed that the conversion factor EE did not vary either seasonally or during a tidal cycle. For the first assumption there is some proof, as Molenplaat Stn A hardly showed any seasonal variation in EE. For Molenplaat Stn B, 2 dates showed higher values but the other EE values were comparable to those found for the other stations. For the Molenplaat Ecoflat stations and Stn V in the Oosterschelde, the data set is too small to draw any conclusion with regard to a possible seasonal influence on EE. Nevertheless, for most stations our ETR-based prediction was close to the C fixation based prediction. Only at Stn B were the differences sometimes large. These differences at Stn B and other sites were due to the observed non-linearity between ETR and $P^{B}$ at higher irradiances (Stn B especially), and to the fact that we used a seasonal averaged value of EE, which in the case of Stn $\mathrm{B}$ might not be valid all the time. Also, by doing this we ignored daily changes in EE, which were observed, but did not show any consistent pattern throughout the year.
A further validation of the PAM technique for other coastal shallow sediments is obviously needed, principally in environments where nutrients could become limiting. A standard comparison between the linear part of the ${ }^{14} \mathrm{C} P-E$ curves, and those produced for the PAM data could be achieved, and when a suitable agreement is found PAM measurements could replace the radiocarbon measurements on wider geographic scale studies.

Acknowledgements. Our special thanks are due to Jan Peene for the $\mathrm{C}$ fixation measurements and assistance in the field and Jan Sinke for chlorophyll analyses. We thank Rod Forster, Kirsten Wolfstein, Peter Herman and 3 unknown referees for useful suggestions. This is publication 2673 of the NIOO. This work is a contribution to the ELOISE Programme (publication number 163) in the framework of the EU-ECOFLAT project carried out under contract ENV4-ct96-0216.

\section{LITERATURE CITED}

Admiraal W, Peletier H, Zomer H (1982) Observations and experiments on the population dynamics of epipelic diatoms from an estuarine mudflat. Estuar Coast Shelf Sci 14:471-487

Barranguet C, Herman PMJ, Sinke JJ (1997) Microphytobenthos biomass and community composition studied by pigment biomarkers: importance and fate in the carbon cycle of a tidal flat. J Sea Res 38:59-70

Barranguet C, Kromkamp J, Peene J (1998) Factors controlling primary production and photosynthetic characteristics of intertidal microphytobenthos. Mar Ecol Prog Ser 173:117-126

Bennet J (1983) Regulation of photosynthesis by reversible phosphorylation of the light-harvesting chlorophyll $a / b$ protein. Biochem J 212:1-13

Blanchard GF, Cariou-Le Gall PA (1992) Photosynthetic characteristics of microphytobenthos in Marennes-Oléron Bay, France: preliminary results. J Exp Mar Biol Ecol 182:1-14

Blanchard GF, Montagna PA (1992) Photosynthetic response of natural assemblages of marine benthic microalgae to short- and long-term variations of incident irradiance in Baffin Bay, Texas. J Phycol 28:7-14

Büchel C, Wilhelm C (1993) In vivo analysis of slow chlorophyll fluorescence induction kinetics in algae: progress, problems and perspectives. Photochem Photobiol 58: 137-148

Cole BE, Cloern JE (1987) An emperical model for estimating phytoplankton productivity in estuaries. Mar Ecol Prog Ser 36:299-305

de Jong DJ, de Jonge VN (1995) Dynamics and distribution of microphytobenthic chlorophyll $a$ in the Western Scheldt estuary (SW Netherlands). Hydrobiologia 311:21-30

Falkowski PG, Wyman K, Ley AC, Mauzerall DC (1986) Relationship of steady-state photosynthesis to fluorescence in eucaryotic algae. Biochim Biophys Acta 849:183-192

Flameling IA (1998) Growth and photosynthesis of eukaryotic microalgae in fluctuating light conditions, induced by vertical mixing. Catholic University Nijmegen, p 1-135

Flameling IA, Kromkamp J (1998) Light dependence of quantum yields for PSII charge separation and oxygen evolution in eucaryotic algae. Limnol Oceanogr 43:284-297

Geel C (1997) Photosystem II electron flow as a measure for 
phytoplankton gross primary production. $\mathrm{PhD}$ thesis, Agricultural University Wageningen, p 67-82

Geel C, Versluis W, Snel JFH (1997) Estimation of oxygen evolution by marine phytoplankton form measurement of the efficiency of Photosystem II electron flow. Photosynth Res 51:61-70

Genty B, Briantais JM, Baker NR (1989) The relationship between quantum yield of photosynthetic electron transport and quenching of chlorophyll fluorescence. Biochim Biophys Acta 990:87-92

Hartig P, Colijn F (1996) Pulse-amplitude-modulation-fluorescence (PAM) a tool for fast assesment of primary productivity in the sea? In: Baeyens J, Dehairs F, Goeyens L (eds) Integrated marine system analysis. Minutes of the first network meeting. Free University Brussels, Brussels, p 103-113

Hartig P, Wolfstein K, Lippemeier S, Colijn F (1998) Photosynthetic activity of natural microphytobenthos populations measured by fluorescence (PAM) and ${ }^{14} \mathrm{C}$-tracer methods: a comparison. Mar Ecol Prog Ser 166:53-62

Heip CHR, Goosen NK, Herman PMJ, Kromkamp J, Middelburg JJ, Soetaert KS (1995) Production and consumption of biological particles in temperate tidal estuaries. Oceanogr Mar Biol Annu Rev 33:1-149

Hofstraat JW, Peeters JCH, Snel JFH, Geel C (1994) Simple determination of photosynthetic efficiency and photoinhibition of Dunaliella tertiolecta by saturating pulse fluorescence measurements. Mar Ecol Prog Ser 103:187-196

Kolber Z, Falkowski PG (1993) Use of active fluorescence to estimate phytoplankton photosynthesis in situ. Limnol Oceanogr 38:1646-1665

Kolber Z, Zehr J, Falkowski PG (1988) Effects of growth irradiance and nitrogen limitation on photosynthetic energy conversion in photosystem II. Plant Physiol 88:923-929

Kolber Z, Wyman KD, Falkowski PG (1990) Natural variability in photosynthetic energy conversion efficiency: a field study in the Gulf of Maine. Limnol Oceanogr 35:72-79

Kolber ZS, Barber RT, Coale KH, Fitzwater SE, Greene RM, Johnson KS, Lindley S, Falkowski PG (1994) Iron limitation of phytoplankton photosynthesis in the equatorial Pacific Ocean. Nature 371:145-149

Kolber ZS, Prásil O, Falkowski PG (1998) Measurements of variable chlorophyll fluorescence using fast repetition rate techniques: defining methodology and experimental protocols. Biochim Biophys Acta 1367:88-106

Krause GH, Weis E (1991) Chlorophyll fluorescence and photosynthesis: the basics. Annu Rev Plant Physiol Plant Mol Biol 42:313-349

Kromkamp J, Peene J (1997) Photosynthesis and nutrient limitation of phytoplankton in the Oosterschelde estuary estimated using PSII quantum efficiency and electron flow. In: Dehairs F, Elskens M, Goeyens L (eds) Integrated marine system analysis: Proc 2 nd network meeting. Free University Brussels, p 3-27

Kromkamp J, Peene J (1999) Estimation of phytoplankton photosynthesis and nutrient limitation in the Eastern Scheldt estuary using variable fluorescence. Aquat Ecol 33:101-104

Kromkamp J, Peene J, van Rijswijk P, Sandee A, Goosen N (1995) Nutrients, light and primary production by phytoplankton and microphytobenthos in the eutrophic, turbid Westerschelde estuary (The Netherlands). Hydrobiologia 311:9-19

Kromkamp J, Barranguet C, Peene J (1998) Determination of microphytobenthos PSII quantum efficiency and photosynthetic activity by means of variable chlorophyll fluorescence. Mar Ecol Prog Ser 162:45-55
Kroon BMA (1994) Variability of photosystem II quantum yield and related processes in Chlorella pyrenoidosa (Chlorophyta) acclimated to an oscillating light regime simulating a mixed photic zone. J Phycol 30:841-852

Kroon BMA, Prézelin BB, Schofield O (1993) Chromatic regulation of quantum yields for photosystem II charge separation, oxygen evolution, and carbon fixation in Heterocapsa pygemaea (Pyrrophyta). J Phycol 29:453-462

Kühl M, Jørgensen BB (1994) The light field of microbenthic communities: radiance distribution and microscale optics of sandy coastal sediments. Limnol Oceanogr 39: 1368-1398

Kühl M, Lassen C, Jørgensen BB (1994) Light penetration and light intensity in sandy marine sediments measured with irradiance and scalar irradiance fiber-optic microprobes. Mar Ecol Prog Ser 105:139-148

Lewis MR, Smith JC (1983) A small volume, short-incubation time method for measurement of photosynthesis as a function of incident irradiance. Mar Ecol Prog Ser 13: 99-102

Lomas MW, Glibert PM (1999) Temperature regulation of nitrate uptake: a novel hypothesis about nitrate uptake and reduction in cool-water diatoms. Limnol Oceanogr 44: $556-572$

MacIntyre HL, Cullen JJ (1995) Fine-scale vertical resolution of chlorophyll and photosynthetic parameters in shallowwater benthos. Mar Ecol Prog Ser 122:227-237

MacIntyre HL, Cullen JJ (1996) Primary production by suspended and benthic microalgae in a turbid estuary: time scales of variability in San Antonio Bay, Texas. Mar Ecol Prog Ser 145:245-268

MacIntyre HL, Geider RJ, Miller DC (1996) Microphytobenthos: the ecological role of the 'secret garden' of unvegetated, shallow-water marine habitats. I. Distribution, abundance and primary production. Estuaries 19: 186-201

Platt T, Jassby AD (1976) The relationship between photosynthesis and light for natural assemblages of coastal marine phytoplankton. J Phycol 12:421-430

Revsbech NP, Jørgensen BB, Brix O (1981) Primary production of microalgae in sediments measured by oxygen microprofile, $\mathrm{H}^{14} \mathrm{CO}_{3}{ }^{-}$and oxygen exchange methods. Limnol Oceanogr 26:717-730

Richardson K (1991) Comparison of ${ }^{14} \mathrm{C}$ primary production determinations made by different laboratories. Mar Ecol Prog Ser 72:189-201

Ruban AV, Horton H (1995) Regulation of non-photochemical quenching of chlorophyll fluorescence in plants. Aust J Plant Physiol 22:221-230

Sabbe K (1997) Systematics and ecology of intertidal benthic diatoms of the Westerschelde estuary (The Netherlands). $\mathrm{PhD}$ thesis, University of Ghent

Schreiber U, Schliwa U, Bilger W (1986) Continuous recording of photochemical and non-photochemical chlorophyll fluorescence quenching with a new type of modulation fluorometer. Photosynth Res 10:51-62

Schreiber U, Hormann H, Neubauer C, Klughammer C (1995) Assessment of photosystem II photochemical quantum yield by chlorophyll fluorescence quenching analysis. Aust J Plant Physiol 22:209-220

Serôdio J, da Silva JM, Catarino F (1997) Nondestructive tracing of migratory rhythms of intertidal benthic microalgae using in vivo chlorophyll fluorescence. J Phycol 33: 542-553

Smith DJ, Underwood GJC (1998) Exopolymer production by intertidal epipelic diatoms. Limnol Oceanogr 43: 1578-1591 
Sullivan MJ, Montcreiff CA (1988) Primary production of edaphic algal communities in a Mississippi salt marsh. J Phycol 24:49-58

Underwood GJC, Kromkamp J (1999) Primary production by phytoplankton and microphytobenthos in estuaries. Adv Ecol Res 29:93-153

Underwood GJC, Phillips J, Saunders K (1998) Distribution of estuarine benthic diatom species along salinity and nutrient gradients. Eur J Phycol 33:173-183

Wetsteyn LPMJ, Kromkamp JC (1994) Turbidity, nutrients

Editorial responsibility: Otto Kinne (Editor),

Oldendorf/Luhe, Germany and phytoplankton primary production in the Oosterschelde (The Netherlands) before, during and after a large-scale coastal engineering project (1980-1990). Hydrobiologia 282/283:61-78

Wiltshire KH, Tolhurst T, Paterson DM, Davison I, Gust G (1998) Pigment fingerprints as markers of erosion and changes in cohesive sediment surface properties in simulated and natural erosion events. In: Black KS, Paterson DM, Cramp A (eds) Sedimentary processes in the intertidal zone. Geol Soc Lond 139:99-114

Submitted: August 27, 1999; Accepted: February 22, 2000 Proofs received from author(s): August 30, 2000 